\title{
Genetic population variation and phylogeny of Sinomenium acutum (Menispermaceae) in subtropical China through chloroplast marker
}

\author{
Ying He ${ }^{1,2, \&}$, Chun Guo ${ }^{3, \&}$, Xiyao Zeng ${ }^{1}$, Hua Yang ${ }^{1,2 *}$, Xingyao Xiong ${ }^{1}$, Ping Qiu ${ }^{2}$ \\ ${ }^{1}$ College of Bioscience and Biotechnology, Hunan Agricultural University, Changsha, \\ Hunan, China \\ ${ }^{2}$ Hunan Zhengqing Pharmaceutical Group Co., Ltd., Huaihua, Hunan, China \\ ${ }^{3}$ First Affiliated Hospital, Hunan University of Chinese Medicine, Changsha, Hunan, \\ China \\ ${ }^{*}$ Corresponding author \\ E-mail: yhua7710@,126.com (Hua Yang) \\ Tel: +86 13548956743 (Hua Yang) \\ \& These authors contributed equally to this work
}

\begin{abstract}
Sinomenium acutum (Menispermaceae) is a traditional Chinese medicine. In recent years, extensive harvesting for medicinal purposes has resulted in a sharp decline in its population. Genetic information is crucial for the proper exploitation and conservation of Sinomenium acutum, but little is known about it at present. In this study, we analyzed 77 samples from 4 populations using four non-coding regions

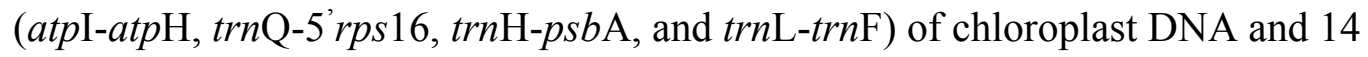
haplotypes (from $\mathrm{C} 1$ to $\mathrm{C} 14$ ) were identified. $\mathrm{C} 1$ and $\mathrm{C} 3$ were common haplotypes,
\end{abstract}


which were shared by all populations, and C3 was an ancestral haplotype, the rest were rare haplotypes. Obvious phylogeographic structure was not existed inferred by $G_{\mathrm{ST}} / N_{\mathrm{ST}}$ test. Mismatch distribution, Tajima's D and Fu's $\mathrm{F}_{\mathrm{S}}$ tests failed to support a rapid demographic expansion in Sinomenium acutum. AMOVA highlighted that the high level of genetic differentiation within population. Low genetic variation among populations illustrated gene flow was not restricted. Genetic diversity analyses demonstrated that the populations of Xuefeng, Dalou, and Daba Mountains were possible refugia localities of Sinomenium acutum. Based on this study, we proposed a preliminary protection strategy for it that $\mathrm{C} 1, \mathrm{C} 3, \mathrm{C} 11$ and $\mathrm{C} 12$ must be collected. These results offer an valuable and useful information for this species of population genetic study as well as further conservation.

\section{Keywords:}

Sinomenium acutum; chloroplast DNA; phylogeny; genetic diversity; population

variation 


\section{Introduction}

Sinomenium acutum, also known as 'qingteng', 'xunfengteng', and 'dianfangji', etc, belongs to the genus Sinomenium and the family Menispermaceae. It includes

Sinomenium acutum (Thunb.) Rehd. et Wils. and S. acutum (Thunb.) Rehd. et Wils. var. cinereum (Diels) Rehd. et Wils., as recorded in the Pharmacopoeia of the People's Republic of China (PPRC). S. acutum is a traditional Chinese medicine that has been widely used to treat arthromyodynia, rheumatism, and similar diseases for more than one thousand years. It has been reported to have anti-inflammatory, anti-arrhythmic, depression, anti-rheumatic, anti-angiogenic, anti-anxiety, immunosuppressive, antihypertensive, and vasodilating effects (Nishida and Satoh. 2007; Ou et al. 2011; Song et al. 2010; Wang and Li. 2011; Yi et al. 2012).

S. acutum grows over a vast geographical area in China (Zhao et al. 2005). In the early stage, we determined the specific distribution range and situation of it by consulting relevant data and field trips. In China Mainland, its roughly horizontal distribution ranges are from $103^{\circ} 76^{\prime} \mathrm{E}$ to $121^{\circ} 75^{\prime} \mathrm{E}$, and from $23^{\circ} 24^{\prime} \mathrm{N}$ to $34^{\circ} 51^{\prime} \mathrm{N}$. Distribution areas are mainly mountainous, such as Qinling Mountains (QL), Dabie Mountains, Daba Mountains (DB), Wushan Mountains, Dalou Mountains (DL), Luoxiao Mountains (LX), Xuefeng Mountains (XF), Wuyi Mountains, Nanling Mountains (Fig. 1). The climate type is mainly subtropical monsoon in this region.

The region has a mild climate, complex terrain, extremely rich in ancient plant lineages (Axelrod et al. 1996), and high species diversity (Myers et al. 2000; Qian and Ricklefs. 2000). The varied terrain of subtropical China provides different 
microhabitats for living organisms, which is considered as one of the most important refugia for these ancient lineages in the middle Miocene (about $15 \mathrm{Ma}$ ) (Axelrod et al. 1996), and it is also the main reason for the high biodiversity compared to other parts of this region (Wu. 1980; Ying et al. 1993; Ying. 2000).

S. acutum has strong adaptability to the environment, but high demand for it has led to uncontrolled exploitation in recent years, causing a sharp population decline. It is therefore urgent to establish appropriate measures of exploitation and protection for S. acutum. Phylogeography has become one of the main research methods for years (Liu et al. 2012; Qiu et al. 2011) used to better understand the evolutionary history of Chinese subtropical flora and provide a basis for protection policy and management. Studies on S. acutum were mainly focused on its pharmacological effects, while its genetic population variation and phylogeny have not yet been conducted except for one of our recent studies based on nuclear ribosomal internal transcribed spacer 2 marker. Phylogeographic studies of $S$. acutum should be carried out in order to better understand the gene genealogies, population variation, and lay the foundation for the formulation of effective conservation strategies.

In this research, we apply cpDNA as a molecular marker for phylogenetic analysis, because the cpDNA has the following characteristics, for instance slow evolution, non-recombinant, maternally inherited, and dispersed via seed (Corriveau and Coleman. 1988; Wolfe et al. 1987).

\section{Materials and methods}

\section{Sampling}


Leaf samples were collected from five populations. Detailed informations, such as population location, number of samples, latitude, and longitude, were listed. Samples were dried in silica gel in the field, and then stored in an ultracold refrigerator $\left(-80^{\circ} \mathrm{C}\right)$ until DNA extraction.

\section{DNA extraction and PCR amplification}

The genomic DNA of $S$. acutum was extracted using Plant Genomic DNA Extraction Kit (Tiangen Biotech (Beijing) Co., Ltd.). The concentration and purity of extracted total DNA were determined using a bioanalyzer and $1.0 \%$ agarose gel, and then the DNA was diluted with deionized-distilled water and stored at $4^{\circ} \mathrm{C}$.

We carried out PCR amplification for four intergenic spacers of cpDNA

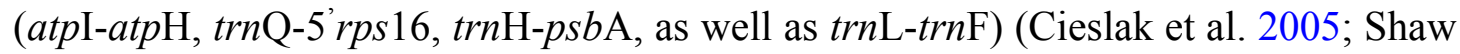
et al. 2005, 2007). The primer sequences were listed in Table 1. PCR amplification was performed using $25-\mu \mathrm{L}$ reaction system, containing 40 ng DNA template, $2.5 \mu \mathrm{L}$ $10 \times$ PCR buffer, $1.0 \mathrm{U}$ Taq DNA polymerase, $2.5 \mathrm{mM} \mathrm{Mg}^{2+}, 0.3 \mathrm{mM} \mathrm{dNTPs}$, and 0.2 $\mu \mathrm{M}$ of each primer. PCR reaction condition was as follows: 4 minutes at $95^{\circ} \mathrm{C} ; 35$ cycles of 30 seconds at $94^{\circ} \mathrm{C}, 1$ minute at $55^{\circ} \mathrm{C}$, and 1 minute at $72^{\circ} \mathrm{C}$; followed by final extension for 10 minutes at $72^{\circ} \mathrm{C}$. The PCR amplification product was assessed by $1.5 \%$ agarose gel electrophoresis in $1 \times$ TAE buffer.

\section{Analysis of sequence data}

All sequences were aligned using Mega version 6.06 (Tamura et al. 2013), and the misread bases were adjusted manually before aligning using Chromas. Polymorphic 
sites, number of haplotypes, haplotype diversity $(H \mathrm{~d})$, and nucleotide diversity $(\pi)$ were accomplished in DnaSP v5.0 (Librado and Rozas. 2009). A recent demographic history of $S$. acutum was investigated using mismatch distribution analysis in DnaSP v5.0 to assess whether intraspecific lineages experienced past population expansions.

Total genetic diversity $\left(H_{\mathrm{T}}\right)$, genetic diversity in within-population $\left(H_{\mathrm{S}}\right)$, interpopulation differentiation ( $G_{\mathrm{ST}}$ : based only on haplotype frequency), and number of substitution types $\left(N_{\mathrm{ST}}\right.$ : based on both haplotype frequency and genetic mutation steps among haplotypes) were calculated using the program PERMUT v2.0 (Pons and Petit. 1996). If the value of $N_{\mathrm{ST}}$ was significantly larger than $G_{\mathrm{ST}}$, we concluded that an obvious phylogeographic structure was present, which means that closely related haplotypes are found more often in the same area than distantly related ones. The proportions of total genetic variance among and within populations were calculated by the analysis of molecular variance (AMOVA) framework in ARLEQUIN v3.5.2.2 (Excoffier and Lischer. 2010; Excoffier et al. 1992), and the significance was tested by 1000 permutations (Sarma et al. 2012; Shepherd et al. 2016; Yu et al. 2014). In addition, Tajima's D and Fu's $F_{S}$ tests were performed to evaluate the hypothesis of population expansion. Gene flow $(\mathrm{Nm})$ was estimated using the equation $N \mathrm{~m}=(1-$ $\left.F_{\mathrm{ST}}\right) / 2 F_{\mathrm{ST}}$.

A haplotype network was constructed using the Median Joining model in TCS1.21 (Clement et al. 2000) to delineate intraspecific relationships of cpDNA haplotypes.

\section{Data available}


https://pan.baidu.com/s/1nvHxaiP password: 2 nth

\section{Results}

\section{DNA polymorphisms and haplotype diversity}

Four cpDNA fragments atpI-atpH, trnQ-5'rps 16 , trn $\mathrm{H}-p s b \mathrm{~A}$, and $\operatorname{trn\mathrm {L}-trn\mathrm {F}}$ were sequenced from 77 individuals of $S$. acutum. The combined length of the four segments ranged from 3658 to $3681 \mathrm{bp}$, with a consensus alignment length of $3692 \mathrm{bp}$. Fourteen haplotypes were identified from all S. acutum individuals (Fig. 2) based on 12 polymorphism sites (regions) (Table 2), which included 6 nucleotide substitutions and 6 indels. All populations, 3 populations with 5 haplotypes, and 1 population with 6 haplotypes. Haplotype $\mathrm{C} 1$ and $\mathrm{C} 3$ were the predominant, shared by all populations. Eleven of the haplotypes were endemic (Fig. 2, Table. 3). The total nucleotide diversity $(\pi)$ and haplotype diversity $(H \mathrm{~d})$ in all populations were $2.19 \times 10^{-3}$ and 0.7553, respectively. Population of XF had the highest nucleotide diversity and haplotype diversity $\left(3.25 \times 10^{-3}, 0.9048\right.$, respectively), followed by DL and DB $(1.75$ $\times 10^{-3}, 0.8312$, and $2.87 \times 10^{-3}, 0.6429$, respectively) (Table 3). These results revealed that the level of genetic differentiation was high in among populations. The geographical distribution of cpDNA haplotypes is shown in Fig. 2.

\section{Population genetic structure}

$H_{\mathrm{T}}$ was greater than $H_{\mathrm{S}}\left(H_{\mathrm{T}}=0.828, H_{\mathrm{S}}=0.710\right)$, revealed the high level of genetic differentiation in all populations. A permutation test illustrated that there was no significant difference between $G_{\mathrm{ST}}$ and $N_{\mathrm{ST}}\left(N_{\mathrm{ST}}=0.139, G_{\mathrm{ST}}=0.142 ; P>0.05\right)$. And 
the value of $N_{\mathrm{ST}}$ was not significantly larger than $G_{\mathrm{ST}}$, therefore, the null hypothesis of a strong phylogeographic pattern was rejected, which showed that haplotypes had little correlation with the geographical areas (Table 4).

AMOVA revealed that $16.38 \%$ of the total variation was distributed at among populations $\left(F_{\mathrm{ST}}=0.16383\right), 83.62 \%$ existed in within populations (Table 5$)$. These results showed that high genetic differentiations existed in within population. The value of $N \mathrm{~m}$ is 2.552 , indicating that the level of gene exchange in among populations was extremely frequent.

\section{Phylogenetic relationships among haplotypes}

The haplotype network of S. acutum was defined (Fig. 3). Haplotype C3 was in the central position of network and was the most widespread haplotype, thus, it may be an ancestral haplotype for all populations. The eleven rare haplotypes $(\mathrm{C} 2, \mathrm{C} 4, \mathrm{C} 5, \mathrm{C} 6$, and from $\mathrm{C} 8$ to $\mathrm{C} 14$ ) were identified in only a single population, $\mathrm{C} 7$ was appeared in two populations. The twelve haplotypes can be obtained by one or multiple mutational step from C3, therefore it making a "star-like" relational network of haplotypes (Fig. 3). The network did not reveal any significant geographical patterns, for instance, haplotype H12, H13, and H14 were distributed in same geographical population, however, H14 has a large genetic distance with $\mathrm{H} 12$ and H13, it means the closely related haplotypes are not found more often in the same area than distantly related ones at all.

\section{Demographic history analyses}

The mismatch distribution of pairwise nucleotide differences exhibited that the 
observed curve was inconsistent with the expected curve for all populations, and exhibited a multimodal (Fig. 4). The values of Tajima's D ( $\mathrm{D}=-0.97017, P>0.1)$ and $\mathrm{Fu}^{\prime} \mathrm{F}_{\mathrm{S}}(\mathrm{Fs}=3.32772, P>0.1)$ were not significantly for all populations (Table 4). These results provide evidence that $S$. acutum did not experience a recent population expansion.

\section{Discussion}

\section{Phylogenetic relationships of haplotypes}

Haplotype C1 and C3 were common, shared by all populations. Since C3 was positioned at the center of the haplotype network and identified in all populations, it was inferred to be ancestral haplotype. Conversely, the twelve haplotypes were surrounded the $\mathrm{C} 3$. Moreover, different mutation steps occurred between the ancestral and derived haplotypes. Six haplotypes (C2, C5, C6, C9, C10 and C14) had one mutational step from $\mathrm{C} 3$, haplotype $\mathrm{C} 8$ had two mutational steps from $\mathrm{C} 3$, and $\mathrm{C} 7 \mathrm{had}$ three mutational steps from $\mathrm{C} 3, \mathrm{C} 1$ had 19 mutational steps from it, and $\mathrm{C} 4$ had 18 mutational steps, the haplotypes of $\mathrm{C} 11, \mathrm{C} 12, \mathrm{C} 13$ exhibited larger numbers of mutational steps, indicating that derivation from the ancestral state does require various time.

According to the haplotype network diagram, the haplotypes are in a radial distribution, that is, the other haplotypes are distributed in a divergent manner around the central haplotype with shorter branch lengths. Combining with the distribution of haplotypes, we can conclude that the population has undergone a barely obvious small-scale regional expansion under the appropriate conditions. However, due to the 
limited ability of population diffusion and the lack of sufficient time after population expansion to established more complex genetic structure, yielded conflicting results. Therefore, we think the most accurately explained that after the glacial period, the population did not experience a significant rapid expansion under optimum conditions.

\section{Genetic diversity and differentiation}

These results, the low genetic variation among populations and high gene flow in the distribution regions, are consistent with these obtained by our previous use of the nuclear ribosomal internal transcribed spacer 2 (ITS2) sequence, but the degree of differentiation was larger than that from ITS2. We suspect that this may due to the genetic characteristics of cpDNA. First, cpDNA is non-recombinant, maternally inherited, and transmitted only through seed, resulting in a slower rate of mutation (Corriveau and Coleman. 1988; Wolfe et al. 1987). In contrast, since nuclear ribosomal DNA (nrDNA) is inherited by parents, the genetic materials is dispersed via seeds and pollen (Hare. 2001), making the mutation rate faster. Thereby, the cpDNA showed greater genetic differentiation than the nuclear DNA. Second, the low ability of seed propagation is the key for the high chloroplast divergence detected in $S$. acutum. Even if birds are fond of eating its fruit would speed up seed dispersal, the high mountains, gorges, and complex paleodrainage basins may be effective barriers to the dispersal and genetic diversification of organisms, which has been reported in multiple phylogeographic studies (He and Jiang. 2014; Yue et al. 2012; Zhang et al. 2010). Third, when cpDNA is used to research gene flow, the effects of male spread 
are often overlooked.

Neither in the haplotype distribution map nor in the $N_{\mathrm{ST}} / G_{\mathrm{ST}}$ test, we failed to detect $S$. acutum with a clear phylogeographic structure. A large number of studies in mainland China show that differential haplotypes usually emerge well subgroups by geographic distance (Liu et al. 2006; Wang et al. 2009). However, we did not found an obvious phylogeographic structure in this study.

Bimodal or multimodal mismatch distributions of pairwise differences between individuals indicate that the population is in a state of equilibrium with a relatively stable size over time, whereas unimodal distributions suggest that the population has recently experienced demographic expansion (Harpending. 1994; Slatkin and Hudson. 1991; Xu et al. 2009; Xue et al. 2014). Significant and non-zero values in Tajima's D and Fu's Fs tests may indicate population expansion (An et al. 2015; Fu. 1997; Jin et al. 2016; Kizawa and Maki. 2016; Tajima. 1989; Wen et al. 2015; Xu et al. 2015). Multimodal mismatch distribution curve, Tajima's D and Fu's $F_{S}$ values failed to support a recent demographic expansion in $S$. acutum, which are consistent with the results that we obtained from ITS2 sequence.

\section{Glacial refugia analyses}

Glacial refugia is not only the place where animals and plants escape the harsh climate during the glacial period, but also the starting point of species redistribution after glacial period. Regions with high genetic diversity are likely to be the shelters of the glacial age, because these populations usually experience longer population dynamics history than those after glacial expansion. The populations of XF, DL, and 
DB have rich genetic diversity may reflect these were possible refugia localities.

However, we believe that more case studies are needed to increase our knowledge

about the phylogeographic history of $S$. acutum in all distribution regions by sufficient sampling.

\section{Develop conservation measure}

The nrDNA reflects both the seed and pollen flow, while the cpDNA only reflects the seed flow. The AMOVA result of cpDNA shows that the seed flow is 2.552 and the seed flow is far less than the pollen flow. Hence, we should mainly rely on the genetic distance of cpDNA haplotype, and combined with the distribution characteristics of haplotype to develop the protection strategy of $S$. acutum. $\mathrm{C} 1$ and $\mathrm{C} 3$ are common haplotypes, C3 is an ancient haplotype that must be collected, and the genetic relationship of $\mathrm{C} 1$ is far apart with $\mathrm{C} 3$, thereby, it is feasible to collect its main distribution area. Haplotypes C2, C5, C6, C7, C8, C9, C10, and C14 are close to C3, so these can be considered not saved; $\mathrm{C} 11$ and $\mathrm{C} 12$ are far away from other haplotypes, consequently, need to hold them; C4 has a close genetic relationship with $\mathrm{C} 1$, and $\mathrm{C} 13$ is near $\mathrm{C} 12$, due to $\mathrm{C} 1$ and $\mathrm{C} 12$ have been preserved, $\mathrm{C} 4$ and $\mathrm{C} 14$ are not need to collected.

At present, unfortunately, there are no data to support these views, as study on its genetic diversity and population structure have not yet been conducted. S. acutum was distributed in vast geographic areas of China, but we only collected few populations and some populations with little samples due to several problems, which might result in inaccurate results. To better understand the population variation and phylogeny 
conditions of $S$. acutum, it is necessary to conduct further phylogeographic study based on a large number of nuclear DNA variation to compensate for the drawbacks that cannot be illustrated by chloroplast DNA.

\section{Conclusion}

In order to better understand the genetic diversity and population variation of $S$. acutum, and establish a basis for developing effective conservation strategies, we sequenced four non-coding regions of cpDNA and identified 14 haplotypes from 77 individuals sampled from 4 locations. $\mathrm{C} 1$ and $\mathrm{C} 3$ were mainly haplotypes, and $\mathrm{C} 3$ was inferred to be ancestral haplotype. C7 was occurred only in two populations, and the rest were unique. In addition, we have illustrated the genetic differentiation was occurred mainly in within population, and gene flow was frequent among populations. At last, our study supported that the population was no distinct geographical structure, failed to undergo an obvious rapid expansion, and Xuefeng, Dalou, Daba Mountains seems to be refuges.

\section{Acknowledgements}

The authors would like to thank Jinjing Teng, Tao Guo, Yuan Chen, Shuaifu Li (College of Bioscience and Biotechnology, Hunan Agricultural University) for their help in experiment. We are especially thankful to three anonymous reviewers for their constructive comments which undoubtedly improved this manuscript.

This study was supported by the Hunan Provincial Major Science and Technology Project (S2015S501P010), Hunan Provincial Science and Technology Plan (2015RS4059). 


\section{Conflict of interests}

The authors declare no conflict of interest.

\section{References}

An M, Zeng LY, Zhang TC, Zhong Y. Phylogeography of Thlaspi arvense (Brassicaceae) in China Inferred from Chloroplast and Nuclear DNA Sequences and Ecological Niche Modeling. Int J Mol Sci. 2015; 16: 13339-13355. https://doi.org/10.3390/ijms160613339 PMID: 26110380 Axelrod DI, Al-Shehbaz I, Raven PH. History of the modern flora of China. In: Zhang A, Wu SG, editors. Floristic characteristics and diversity of East Asian plants. Beijing: China Higher Education Press; 1996. pp. 43-45.

Cieslak T, Polepalli JS, White A, Muller K, Borsch T, et al. Phylogenetic analysis of Pinguicula (Lentibulariaceae): chloroplast DNA sequences and morphology support several geographically distinct radiations. American Journal of Botany. 2005; 92: 1723-1736.

Clement M, Posada D, Crandall KA. TCS: a computer program to estimate gene genealogies. Mol Ecol. 2000; 9: 1657-1659. PMID: $\underline{11050560}$

Corriveau JL, Coleman AW. Rapid screening method to detect potential biparental inheritance of plastid DNA and results for over 200 angiosperm species. Am J Bot. 1988; 75: 1443-1458.

https://doi.org/10.2307/2444695

Excoffier L, Lischer H. Arlequin suite ver 3.5: a new series of programs to perform population genetics analyses under Linux and Windows. Mol Ecol Resour. 2010; 10: 564-567.

https://doi.org/10.1111/j.1755-0998.2010.02847.x PMID: 21565059

Excoffier L, Smouse PE, Quattro JM. Analysis of molecular variance inferred from metric distances among DNA haplotypes: application to human mitochondrial DNA restriction data. Genetics. 1992; 131: 479-491. PMID: 1644282

Fu Y. Statistical tests of neutrality of mutations against population growth, hitchhiking and background selection. Genetics. 1997; 147: 915. PMID: 9335623

Hare MP. Prospects for nuclear gene phylogeography. Trends Ecol Evol. 2001; 16: 700-706.

Harpending HC. Signature of ancient population growth in a low-resolution mitochondrial DNA mismatch distribution. Hum Biol. 1994; 66: 591-600. PMID: $\underline{8088750}$

He K, Jiang XL. Sky islands of southwest China. I: An overview of phylogeographic patterns. Chin Sci Bull. 2014; 59: 585-597. 
Jin DP, Lee JH, Xu B, Choi BH. Phylogeography of East Asian Lespedeza buergeri (Fabaceae) based on chloroplast and nuclear ribosomal DNA sequence variations. J Plant Res. 2016; 129: 793-805. https://doi.org/10.1007/s10265-016-0831-2

Kizawa A, Maki M. Phylogeography of Arabis serrata (Brassicaceae) in the Japanese Archipelago based on chloroplast DNA variations. Plant Spec Biol. 2016; 31: 65-72.

https://doi.org/10.1111/1442-1984.12072

Librado P, Rozas J. DnaSP v5: a software for comprehensive analysis of DNA polymorphism data. Bioinformatics. 2009; 25: 1451-1452. https://doi.org/10.1093/bioinformatics/btp187 PMID: 19346325 Liu JQ, Sun YS, Ge XJ, Gao LM, Qiu YX. Phylogeographic studies of plants in China: advances in the past and directions in the future. J Syst Evol. 2012; 50: 267-275.

https://doi.org/10.1111/j.1759-6831.2012.00214.x

Liu JQ, Wang YJ, Wang AL, Hideaki O, Abbott RJ. Radiation and diversification within the Ligularia-Cremanthodium-Parasenecio complex (Asteraceae) triggered by uplift of the Qinghai-Tibetan Plateau. Mol Phylogenet Evol. 2006; 38: 31-49. https://doi.org/10.1016/j.ympev.2005.09.010 PMID: $\underline{16290033}$

Myers N, Mittermeier RA, Mittermeier CG, da Fonseca GAB, Kent J. Biodiversity hotspots for conservation priorities. Nature. 2000; 403: 853-858.

Nishida S, Satoh H. Cardiovascular Pharmacology of Sinomenine: The Mechanical and Electropharmacological Actions. Drug Target Insights. 2007; 2: 97-104. PMID: 21901066 Ou YQ, Li WD, Li XJ, Lin ZB, Li M. Sinomenine reduces invasion and migration ability in fibroblast-like synoviocytes cells co-cultured with activated human monocytic THP-1 cells by inhibiting the expression of MMP-2, MMP-9, CD147. Rheumatology International. 2011; 31: 1479-1485. https://doi.org/10.1007/s00296-010-1506-2 PMID: 20473759

Pons O, Petit RJ. Measuring and testing genetic differentiation with ordered versus unordered alleles. Genetics. 1996; 144: 1237-1245. PMID: $\underline{8913764}$

Qian H, Ricklefs RE. Large-scale processes and the Asian bias in species diversity of temperate plants. Nature. 2000; 407: 180-182. https://doi.org/10.1038/35025052 PMID: 11001054

Qiu YX, Fu CX, Comes HP. Plant molecular phylogeography in China and adjacent regions: tracing the genetic imprints of Quaternary climate and environmental change in the world's most diverse temperate flora. Mol Phylogenet Evol. 2011; 59: 225-244. https://doi.org/10.1016/j.ympev.2011.01.012 Sarma DK, Prakash A, O'Loughlin SM, Bhattacharyya DR, Mohapatra PK, et al. Genetic population 
structure of the malaria vector Anopheles baimaii in north-east India using mitochondrial DNA. Malar J. 2012; 11:76. https://doi.org/10.1186/1475-2875-11-76 PMID: 22429500

Shaw J, Lickey EB, Beck JT, Farmer SB, Liu WS, et al. The tortoise and the hare II: relative utility of 21 noncoding chloroplast DNA sequences for phylogenetic analysis. American Journal of Botany. 2005; 92: 142-166.

Shaw J, Lickey EB, Schilling EE, Small RL. Comparison of whole chloroplast genome sequences to choose noncoding regions for phylogenetic studies in angiosperms: the tortoise and the hare III. American Journal of Botany. 2007; 94: 275-288.

Shepherd LD, de Lange PJ, Cox S, McLenachan PA, Roskruge NR, et al. Evidence of a Strong Domestication Bottleneck in the Recently Cultivated New Zealand Endemic Root Crop, Arthropodium cirratum (Asparagaceae). Plos One. 2016; 11: e0152455. https://doi.org/10.1371/journal.pone.0152455 PMID: 27011209

Slatkin M, Hudson RR. Pairwise comparisons of mitochondrial DNA sequences in stable and exponentially growing populations. Genetics. 1991; 129: 555-562. PMID: 1743491 Song SH, Shen XY, Tang Y, Wang ZX, Guo WY, et al. Sinomenine pretreatment attenuates cold ischemia/reperfusion injury in rats: The role of heme oxygenase-1. Int Immunopharmacol. 2010; 10: 679-684. https://doi.org/10.1016/j.intimp.2010.03.011 PMID: 20353835

Tajima F. Statistical method for testing the neutral mutation hypothesis by DNA polymorphism. Genetics. 1989; 123: 585. PMID: 2513255

Tamura K, Stecher G, Peterson D, Filipski A, Kumar S. MEGA6: molecular evolutionary genetics analysis version 6.0. Mol Biol Evol. 2013; 30: 2725-2729. https://oi.org/10.1093/molbev/mst197 PMID: 24132122

Wang L, Abbott RJ, Zheng W, Chen P, Wang Y, et al. History and evolution of alpine plants endemic to the Qinghai-Tibetan Plateau: Aconitum gymnandrum (Ranunculaceae). Mor Ecol, 2009; 18:709-721. https://doi.org/10.1111/j.1365-294X.2008.04055.x PMID: 19175501

Wang QX, Li XK. Immunosuppressive and anti-inflammatory activities of sinomenine. Int Immunopharmacol. 2011; 11: 373-376. https://doi.org/10.1016/j.intimp.2010.11.018

Wen ZB, Xu Z, Zhang HX, Feng Y. Chloroplast phylogeography of a desert shrub, Calligonum calliphysa, ( Calligonum, Polygonaceae), in arid Northwest China. Biochem Syst Ecol. 2015; 60: 56-62. https://doi.org/10.1016/j.bse.2015.03.001

Wolfe KH, Li WH, Sharp PM. Rates of Nucleotide Substitution Vary Greatly among Plant 
Mitochondrial, Chloroplast, and Nuclear DNAs. Proc Natl Acad Sci U S A. 1987; 84: 9054-9058.

PMID: $\underline{3480529}$

Wu ZY. China’s vegetation. Beijing: Science Press; 1980.

Xu J, Chan T, Tsang LM, Chu KH. Phylogeography of the mitten crab Eriocheir sensu stricto in East Asia: pleistocene isolation, population expansion and secondary contact. Mol Phylogenet Evol. 2009;

52: 45-56. https://doi.org/10.1016/j.ympev.2009.02.007 PMID: 19236929

Xu J, Deng M, Jiang XL, Westwood M, Song YG, et al. Turkington R. Phylogeography of Quercus glauca, (Fagaceae), a dominant tree of East Asian subtropical evergreen forests, based on three chloroplast DNA interspace sequences. Tree Genet Genomes. 2015; 11: 805.

https://doi.org/10.1007/s11295-014-0805-2

Xue DX, Wang HY, Zhang T, Liu JX. Population genetic structure and demographic history of Atrina pectinate based on mitochondrial DNA and microsatellite markers. PLoS One. 2014; 9: e95436. https://doi.org/10.1371/journal.pone.0095436 PMID: 24789175

Yi L, Liang ZT, Peng Y, Yao X, Chen HB et al. Tissue-specific metabolite profiling of alkaloids in Sinomenii Caulis using laser microdissection and liquid chromatography-quadrupole/time of flight-mass spectrometry. J Chromatogr A. 2012; 1248: 93-103.

https://doi.org/10.1016/j.chroma.2012.05.058 PMID: 22721764

Ying TS, Zhang YL, Bufford DE. The endemic genera of seed plants of China. Beijing: Science Press; 1993.

Ying TS. Species diversity and distribution patterns of seed plants in China. Biodivers Sci. 2001; 9: 393-398.

Yu D, Chen M, Tang QY, Li XJ, Liu HZ. Geological events and Pliocene climate fluctuations explain the phylogeographical pattern of the cold water fish Rhynchocypris oxycephalus, (Cypriniformes: Cyprinidae) in China. BMC Evol Biol. 2014; 14: 225. https://doi.org/10.1186/s12862-014-0225-9 PMID: 25344323

Yue LL, Chen G, Sun WB, Sun H. Phylogeography of Buddleja crispa (Buddlejaceae) and its correlation with drainage system evolution in southwestern China. Am J Bot. 2012; 99: 1726-1735 https://doi.org/10.3732/ajb.1100506

Zhang DR, Chen MY, Murphy RW, Che J, Pang JF, et al. Genealogy and palaeodrainage basins in Yunnan Province: phylogeography of the Yunnan spiny frog, Nanorana yunnanensis (Dicroglossidae). Mol Ecol. 2010; 19: 3406-3420 https://doi.org/10.1111/j.1365-294X.2010.04747.x PMID: 20666999 

available under aCC-BY 4.0 International license.

Zhao ZZ, Liang ZT, Zhou H, Jiang ZH, Liu ZQ, et al. Quantification of sinomenine in caulis sinomenii collected from different growing regions and wholesale herbal markets by a modified HPLC method.

Biol Pharm Bull. 2005; 28: 105-9. PMID: 15635172 


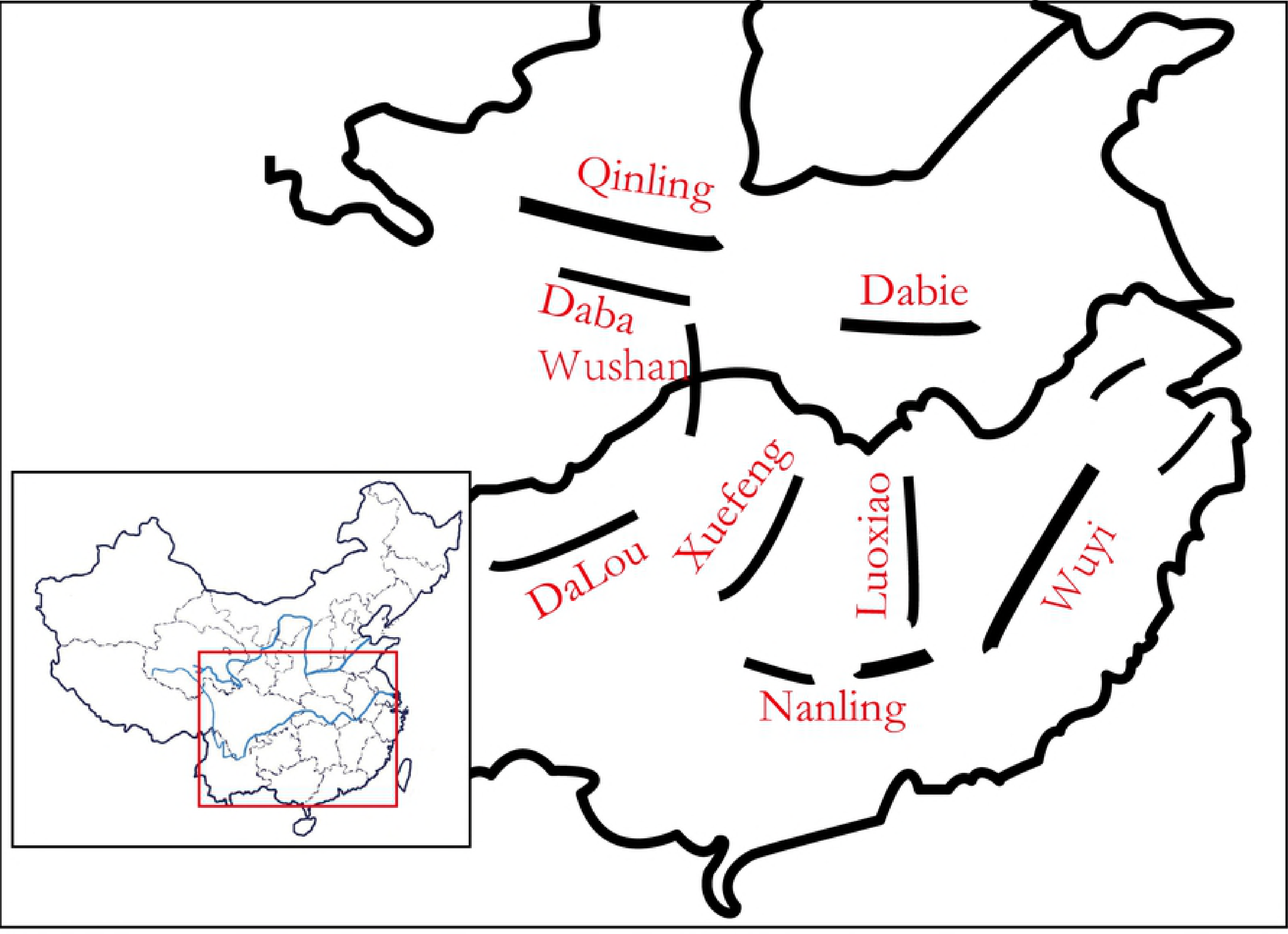

Figure 


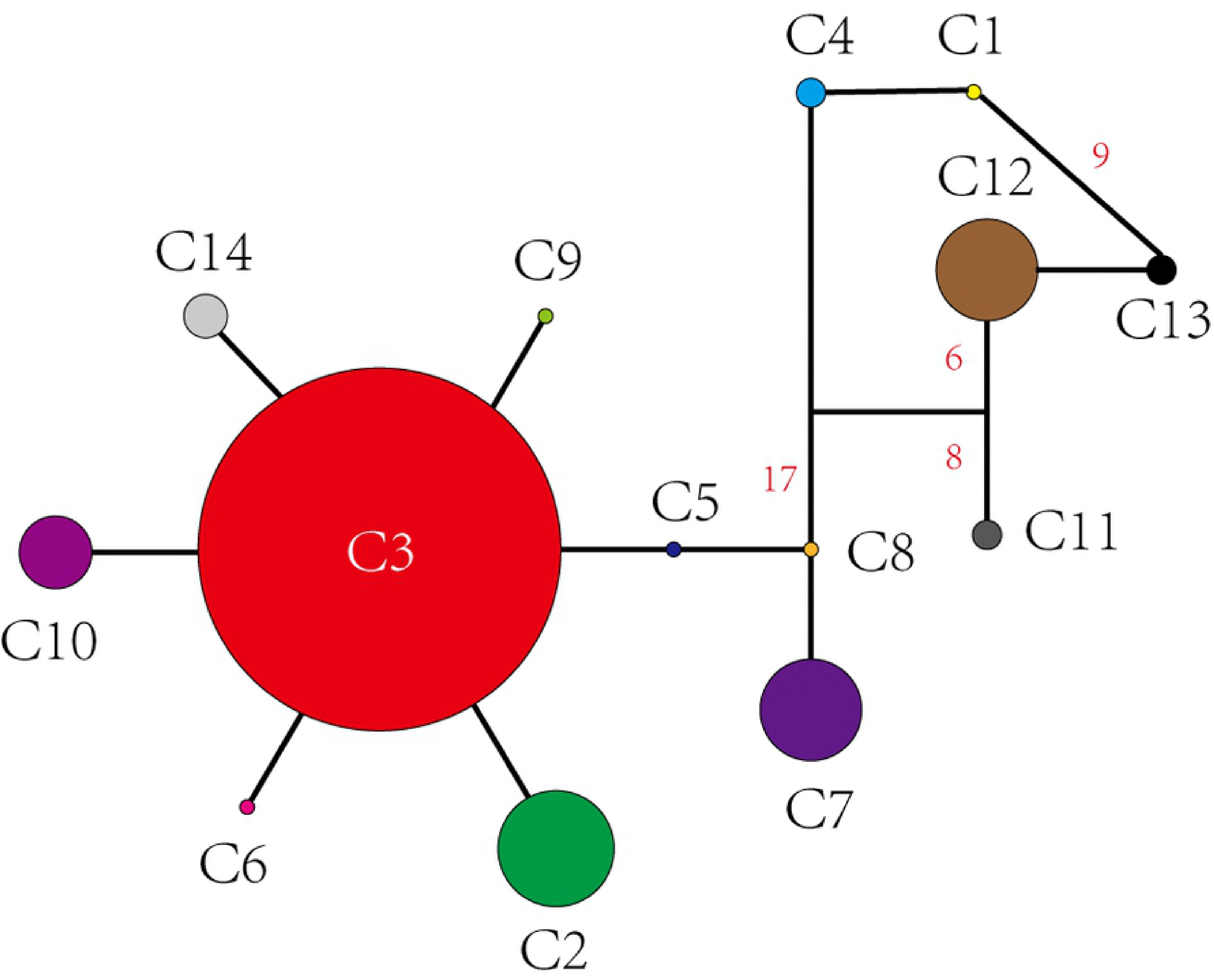

Figure 


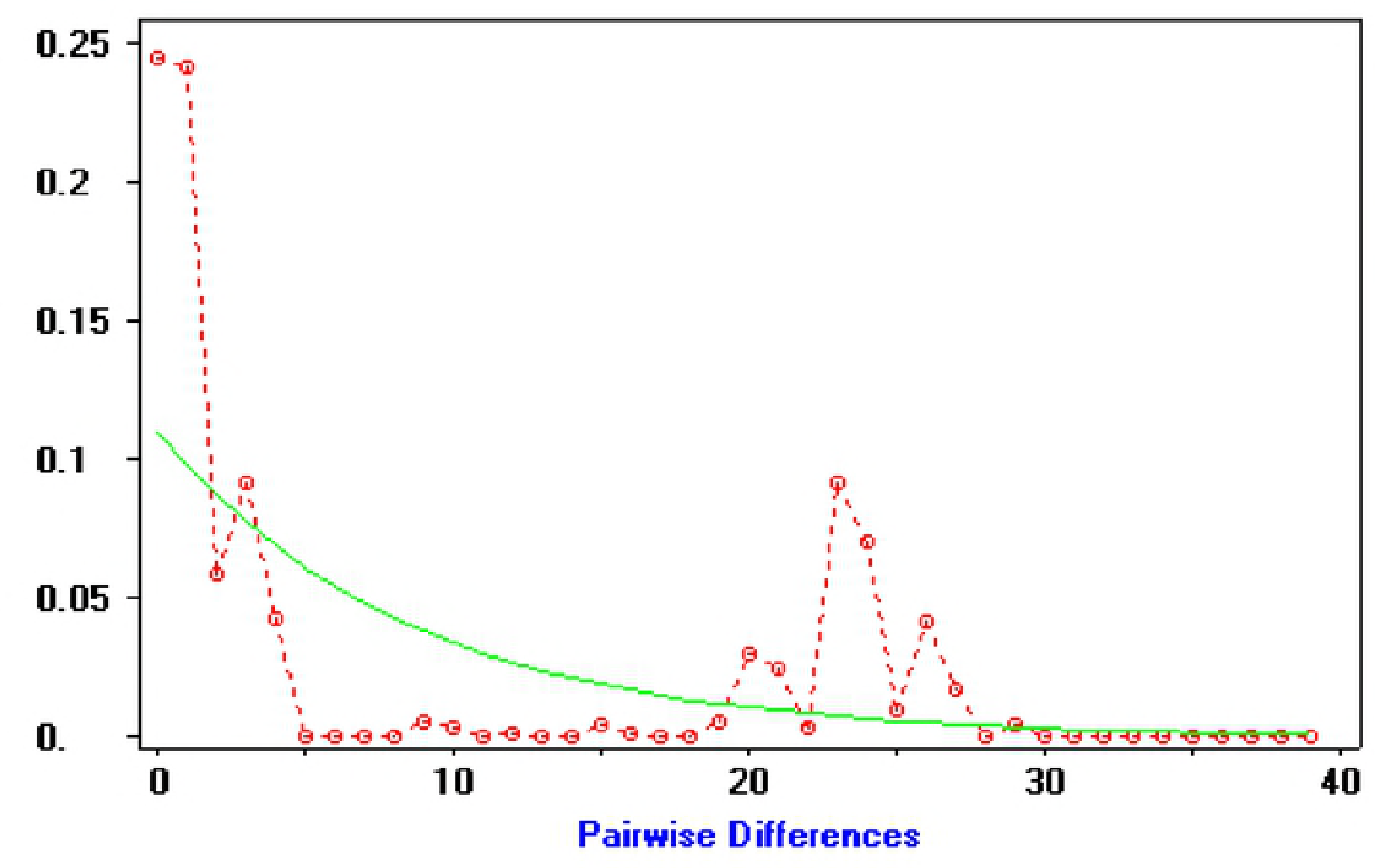

Figure 
Table 4. Estimates of within population diversity $\left(H_{\mathrm{S}}\right)$, total gene diversity $\left(H_{\mathrm{T}}\right)$, interpopulation genetic differentiation $\left(G_{\mathrm{ST}}\right)$, number of substitution types $\left(N_{\mathrm{ST}}\right)$, and mismatch distribution analysis

\begin{tabular}{|c|c|c|c|c|c|c|c|c|c|}
\hline \multirow{2}{*}{ Population } & \multirow{2}{*}{$H_{\mathrm{T}}(\mathrm{se})$} & \multirow{2}{*}{$H_{\mathrm{S}}(\mathrm{se})$} & \multirow{2}{*}{$G_{\mathrm{ST}}$} & \multirow{2}{*}{$N_{\mathrm{ST}}$} & \multirow{2}{*}{$\mathbf{P}$} & \multicolumn{2}{|c|}{ Tajima's D test } & \multicolumn{2}{|c|}{ Fu's Fs test } \\
\hline & & & & & & D & p & Fs & p \\
\hline All & $\begin{array}{c}0.828 \\
(0.0913)\end{array}$ & $\begin{array}{c}0.710 \\
(0.0994)\end{array}$ & 0.142 & 0.139 & $\begin{array}{c}0.441 \\
\text { NS }\end{array}$ & -0.97017 & $\begin{array}{c}\mathrm{P}>0.1 \\
\mathrm{NS}\end{array}$ & 3.32772 & $\begin{array}{c}\mathrm{P}>0.1 \\
\mathrm{NS}\end{array}$ \\
\hline
\end{tabular}

NS, not significant 
Table 5. Analysis of molecular variance (AMOVA) for the 4 populations of Sinomenium acutum

\begin{tabular}{ccccc}
\hline Source of variation & d.f. & Sum of squares & $\begin{array}{c}\text { Variance } \\
\text { components }\end{array}$ & $\begin{array}{c}\text { Percentage of } \\
\text { variation }\end{array}$ \\
\hline Among populations & 3 & 48.540 & $0.69563 \mathrm{Va}$ & 16.38 \\
Within populations & 73 & 259.174 & $3.55033 \mathrm{Vb}$ & 83.62 \\
Total & 76 & 307.714 & & \\
& & & & \\
& & & & \\
\end{tabular}

bioRxiv preprint doi: https://doi.org/10.1101/449900; this version posted October 22, 2018. The copyright holder for this preprint (which was not certified by peer review) is the author/funder, who has granted bioRxiv a license to display the preprint in perpetuity. It is made 
Table 1. The primer sequences of noncoding chloroplast DNA regions

\begin{tabular}{ccc}
\hline Primer & Forward sequence $\left(5^{\prime}-3^{\prime}\right)$ & Reverse sequence (5'-3') \\
\hline atp $\mathrm{I}-a t p \mathrm{H}$ & TATTTACAAGYGGTATTCAAGCT & CCAAYCCAGCAGCAATAAC \\
trnQ-5' $r p s 16$ & GCGTGGCCAAGYGGTAAGGC & GTTGCTTTYTACCACATCGTTT \\
$t r n \mathrm{H}-p s b \mathrm{~A}$ & CGCGCATGGTGGATTCACAATCC & GTTATGCATGAACGTAATGCTC \\
$t r n \mathrm{~L}-t r n \mathrm{~F}$ & CGAAATCGGTAGACGCTACG & ATTTGAACTGGTGACACGAG \\
\hline
\end{tabular}

bioRxiv preprint doi: https://doi.org/10.1101/449900; this version posted October 22, 2018. The copyright holder for this preprint (which was not certified by peer review) is the author/funder, who has granted bioRxiv a license to display the preprint in perpetuity. It is made

\section{Figure}


Table 2. Variable nueleotide sites in 14 haplotypes of Sinomenium acutum

\begin{tabular}{|c|c|c|c|c|c|c|c|c|c|c|c|c|}
\hline Hap & 36 & 221 & 1915 & 1984 & 2077 & 2199-2206 & 2228-2229 & 2318-2334 & $2445-2450$ & 2726 & 2772 & 3063 \\
\hline $\mathrm{Cl}$ & A & - & G & $\mathrm{T}$ & C & (n) & - & 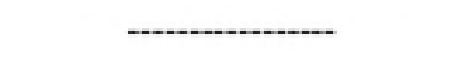 & AAATAT & A & - & $\mathrm{T}$ \\
\hline $\mathrm{C} 2$ & A & - & G & G & A & $\ldots$ & $\mathrm{T}$ - & TACTAATAAAAATCAAT & AAATAT & A & - & $\mathrm{T}$ \\
\hline $\mathrm{C} 3$ & A & - & G & G & $\mathrm{A}$ & $\ldots$ & T- & TACTAATAAAAATCAAT & AAATAT & A & A & $\mathrm{T}$ \\
\hline $\mathrm{C} 4$ & $\mathbf{A}$ & - & G & $\mathrm{T}$ & $\mathrm{C}$ & $\ldots$ & -- & ...................... & AAATAT & A & A & $\mathrm{T}$ \\
\hline Cs & A & - & G & G & A & n....... & 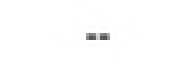 & TACTAATAAAAATCAAT & AAATAT & A & A & $\mathrm{T}$ \\
\hline $\mathrm{C6}$ & A & - & G & G & A & .......... & T- & TACTAATAAAAATCAAT & AAATAT & $\mathrm{T}$ & A & $\mathrm{T}$ \\
\hline $\mathrm{C7}$ & A & $=$ & G & G & C & n....... & - & TACTAATAAAAATCAAT & AAATAT & A & A & $\mathrm{C}$ \\
\hline $\mathrm{C} 8$ & A & $\cdot$ & G & G & C & $\cdots$ & 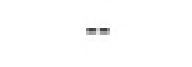 & TACTAATAAAAATCAAT & AAATAT & A & A & $\mathrm{T}$ \\
\hline $\mathrm{C9}$ & A & $\mathrm{T}$ & G & G & A & n...... & T- & TACTAATAAAAATCAAT & AAATAT & A & A & $\mathrm{T}$ \\
\hline $\mathrm{C} 10$ & A & $=$ & A & G & A & n........ & T- & TACTAATAAAAATCAAT & AAATAT & A & A & $\mathrm{T}$ \\
\hline $\mathrm{C} 11$ & A & - & G & G & A & TGTATCTA & $\mathrm{TT}$ & (n..................... & AAATAT & A & A & $\mathbf{T}$ \\
\hline $\mathrm{C} 12$ & A & - & G & G & A & $\ldots$ & T- & n...n. & $\ldots$ & A & A & $\mathrm{T}$ \\
\hline $\mathrm{C} 13$ & A & - & G & G & A & (n...... & T- & 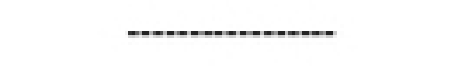 & $\ldots$ & A & - & $\mathrm{T}$ \\
\hline $\mathrm{C} 14$ & $\mathrm{C}$ & - & G & G & A & (n) & $\mathrm{T}-$ & TACTAATAAAAATCAAT & AAATAT & A & A & $\mathrm{T}$ \\
\hline
\end{tabular}

\section{Figure}


Table 3. Sample information and haplotype distribution of Sinomenium acutum

\begin{tabular}{|c|c|c|c|c|c|c|}
\hline Population (code) & $\begin{array}{l}\text { Longitude } \\
\quad\left({ }^{\circ} \mathrm{E}\right)\end{array}$ & $\begin{array}{l}\text { Latitude } \\
\qquad\left({ }^{\circ} \mathrm{N}\right)\end{array}$ & $\begin{array}{l}\text { Sample } \\
\text { size }\end{array}$ & $\begin{array}{c}\text { Haplotypes (No. } \\
\text { of individuals) }\end{array}$ & $H \mathrm{~d}$ & $\pi / 10^{-3}$ \\
\hline $\begin{array}{l}\text { Qinling Mountains } \\
\text { (QL) }\end{array}$ & 107.24 & 34.36 & 19 & $\begin{array}{l}\mathrm{Cl}(2), \mathrm{C} 3(14) \\
\mathrm{C} 6(1), \mathrm{C} 7(1) \\
\quad \mathrm{C} 8(1)\end{array}$ & 0.4620 & 0.22 \\
\hline $\begin{array}{c}\text { Daba Mountains } \\
\text { (DB) }\end{array}$ & 112.12 & 32 & 29 & $\begin{array}{l}\mathrm{Cl}(1), \mathrm{C} 3(16) \\
\mathrm{C} 12(7), \mathrm{C} 13(2) \\
\mathrm{C} 14(3)\end{array}$ & 0.6429 & 2.87 \\
\hline \multicolumn{5}{|c|}{ 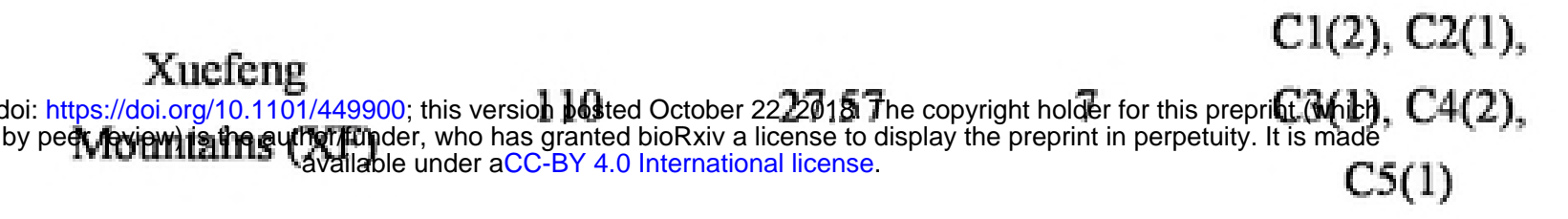 } & 0.9048 & 3.25 \\
\hline $\begin{array}{l}\text { Dalou Mountains } \\
\text { (DL) }\end{array}$ & 106.93 & 27.73 & 22 & $\begin{array}{l}\mathrm{C} 1(3), \mathrm{C} 3(5) \\
\mathrm{C} 7(6), \mathrm{C} 9(1) \\
\mathrm{C} 10(5), \mathrm{C} 11(2)\end{array}$ & 0.8312 & 1.75 \\
\hline
\end{tabular}

